\title{
On the Teaching Quality Guarantee System of College and University Lasheng Li
}

Jianghan University Hubei, Wuhan, 430056

\author{
Keywords: Teaching Quality; Design Principles; Guarantee System; Operational Mechanisms
}

\begin{abstract}
With the rapid growth of educational scale and student recruiment in recent years, the teaching quality is becoming a more serious problem. So it's urgent to establish a teaching quality guarantee system in college and univeristy. When designing the teaching quality guarantee system, a few principles must be take into consideration, such as the head of the faculty be the first responsibility person, all the staff be involved in the practice, the activity should be systematic and practical as well as extended. Teaching quality guarantee system is composed of teaching management, teaching research, teaching service, teaching assessment and teaching feedback. Among them, teaching management is the core, teaching service the basis, teaching assessment the fundament, teaching feedback the key and teaching research the necessary booster. They co-exist and interact with each other. They won't work when one is absent, let alone the effect of a system.

Since 1990s, our country has witnessed a continuous development in colleges and universities. Consider the scale of running a school and the number of students at colleges and universities: the number amounted to 1867 by the end of 2006, (of which there were 720 undergraduate colleges, 1147 higher vocational colleges, and 318 independent colleges); the number of students was 25000000 and the gross enrollment rate of higher education was the $22 \%$. Judging by the international standard, China has entered the phase of popularization of higher education. While at the same time, China is a country running a big education with limited finance. Confronted with the limited resources, we are in a dilemma to balance the quantity and quality: on the one hand, we should meet citizens' strong desire of receiving higher education through the increase of enrollment rate to the greatest extent; on the other hand, we also hope the increasing enrollment will not disturb the quality of higher education. However, the fact was that there appeared problem in the quality of teaching which cannot be ignored. It is acknowledged that teaching is the central work in colleges and universities and teaching quality is the lifeline to colleges. Therefore, establishing and improving the guarantee system of teaching quality of colleges and universities in China has become a pressing matter.
\end{abstract}

\section{Principles of Teaching Quality Guarantee System}

In the design of the teaching quality guarantee system, we should grasp the following five principles:

"Top Leaders" Should Be the First Persons to Take Responsibility

Everyone is responsible for teaching quality, but different people play different roles in the "quality project" because of their different positions, titles and positions. From the management perspective, a college or a university is often performed by a deputy president and a vice president in charge of the teaching work independently. The advantage of this division is making principal leaders have more energy to the overall work, but the disadvantage that the center of teaching status is difficult to obtain is also obvious. Therefore, in the design of teaching quality guarantee system, it is necessary for the school party committee secretary, president and secretary of party committee of academy dean to be the first responsible persons in quality of teaching work and the vice principal, vice president for teaching quality as direct responsible persons to meet the manpower, material resources and financial needs in teaching work.

Overall Principle

Improving the quality of teaching needs efforts of overall students and teaching staff. In other words, everyone is a member in the quality assurance system. But due to their different locations in the system, they play their roles more or less directly or indirectly. Among them, leadership is the 
key, functional branch is the core, faculties (departments), staff rooms and teachers are the basis and students are the main body of teaching work. They should cooperate actively to form a resultant force.

\section{Systematic Principle}

The quality of teaching to teachers is the result of joint efforts closely concerned with students, teaching materials, equipment and facilities, also with the idea of running a school, such as level of management software. The quality of teaching is a complete teaching, management and service system formed by school, college (Department), functional departments, staff rooms and class of multi-levels which is arranged in a crisscross pattern of the network. As the teaching main body, the progress of students' enrollment, cultivation and employment is a mutual connection and influence system. Therefore, the design of teaching quality guarantee system must implement the principle of systematic. Otherwise, it will lead to losses and expected results cannot be achieved.

long- term principle

Improving the quality of teaching is a process that is achieved in the process of the teaching practice, rather than relying on several screening and assessment. Moreover, there is no end in improving the quality of teaching. The design, construction and operation of guarantee system of teaching quality should also focus on the long-term, continuous modification and tend to be scientific, reasonable and perfect.

Feasible principle

In the design of the guarantee system of teaching quality, we must pay special attention to its feasibility, or the practical significance will lose, or even play a counter-productive part. Firstly, time should be feasible that does not require much time and energy; secondly, finance should be feasible to try to avoid spending more money; thirdly, there should be clear evaluation criteria, convenient operation and measures; lastly, it must be effect feasible for the general staff and students to accept.

\section{Construction of Teaching Quality Guarantee System}

Teaching quality assurance system is mainly composed of teaching management system, teaching system, teaching system, teaching evaluation and teaching feedback system.

Teaching management system is a flexible, authoritative and efficient daily teaching management system led by the executive president, with focusing office of teaching affairs as a center and each college (department, ministry ) cooperating closely. Teaching management system mainly includes the command system and the implementation of the system. Command system is form by the president, college (department) leaders taking charge of teaching work and leaders of office of teaching affairs. They regularly research and solve the major problems in the work of teaching management. In many universities, this function is mainly performed by the school teaching guidance committee. Executive system consists of the office of academic affairs and all levels of teaching units. The office of teaching affairs is the center of the executive system and its work directly reflects the whole school teaching work. Therefore, we must strengthen the management function, the structure of the sound department and equip high quality, relatively stable administrative cadres. In the implementation of system, the administration of college (department, ministry) is crucial and its teaching work efficiency and quality of has a considerable impact. Therefore, it should be equipped with staff with sophisticated teaching and management knowledge to form a competent president management group. Teaching management work is extremely easy to have problems with complicated clues and trivial. Currently, colleges and universities have attached great importance to teachers' team construction, but neglected the construction of the teaching management staff. This requires teaching management staff must work carefully, responsibly heart is strong and with broad knowledge and certain rules of teaching. Therefore, the comprehensive quality of teaching management staff should not be less than full-time teachers.

Teaching has its own rule and it is a deep knowledge, a comprehensive "art". In order to guarantee and improve teaching quality, carrying out teaching and research and establishing the 
teaching research system are very necessary. China's higher education is experiencing a profound change of hitherto unknown. In the higher education reform, there will continuously be problems of theory and practice about reform and development that need urgent answers through research and then with new correct theory to guide the practice of reform. With the progress of science and technology and the development of the society, many ideas and methods considered correct in the past today has reduced the teaching quality that must be analyzed, researched and reformed. Teaching and research system is presented in two forms: one is the embodiment of full-time teachers and management staff with their job for teaching and research, the other is the establishment of teaching research institutions and researchers specialized in teaching and research work forming a part-time and full-time mixed teaching research team. Focusing on the theory study, teaching research should conduct practical and valuable research more to promote teaching reform and improve teaching quality. Worryingly, colleges and universities generally have not attached importance to teaching and research for a long time. Take Jianghan University as an example. There was a stark contrast that the average annual declarations above municipal level of non teaching scientific research project was 450 in the past three years, but declaration of teaching research project was less than 30. Hubei Province selected once every two years for the outstanding social sciences achievement award, and once every four years for the excellent teaching achievement award. Many colleges and universities often depend on academic achievements generally. This bias needs to be corrected.

Teaching service system is the basic guarantee for improving the quality of teaching. School logistics service and management staff should be fully aware of service work and teaching quality are closely bound up, and strive to improve service levels, provide high quality logistics support to give warm and thoughtful services and amplify formalities to the convenience of teachers and students. Schools should spare no effort to provide material support to teaching and reform. In the information age, teachers should keep contact to the domestic and foreign related disciplines, development of cutting-edge trends and related knowledge, therefore they need Internet and corresponding technical support; today the teaching means of blackboard and chalk has been lagging far behind and the teaching means need modern equipment and facilities. A reform scheme, only with the enthusiasm of teachers and lacking of the necessary material conditions, could not be finished. Previous teaching service work scattered in various departments with complex procedures, caused a waste of time and energy. For example, multimedia classrooms are in the charge of audio-visual department computer equipment management department, and tables and chairs are in the charge of logistics management department, while classroom usage is in the charge of academic departments The author thinks, a coordination mechanism should be established on the basis of internal management system and logistics socialization reform directly subordinated to the executive principal, involved teaching service department, supply department, printing department, audio-visual sector and repair departments as a unified management to provide convenient, fast, high-quality services and material guarantee.

Teaching evaluation system functions as a teaching evaluation and supervision, which plays an important role in guiding and promoting the supervision. Colleges and universities are equipped with general staff of strong sense of responsibility and rich teaching experience as teaching supervision group. Supervisors should always enter the first-line teaching with methods of taking lectures, investigating, discussing to check and supervise the teaching order and quality. With the continuous development of higher education, education and teaching reform, new issue or topic will appear continuously. Colleges and universities should regularly or irregularly check their teaching work to establish teaching quality monitoring system and make it become a regular system of work. In addition to the steering of supervision group, teaching evaluation system should also include teachers' and students' evaluation to teaching. The three main evaluation of the teaching evaluation have their own advantages and disadvantages and can be completed together to serve as most important assessment of teachers' promotion.

In the teaching process, teachers' teaching effect, the quality of student learning and information about the problem should be able to make a quick, sensitive, accurate and reliable system to reflect 
the feedback, which is to establish teaching quality feedback system. Feedback can be achieved through a variety of channels, colleges and universities should be in accordance with their own specific conditions with the features of the school's effective way. In recent years, office of academic affairs of Jianghan University has carried out student information system, in which each class appoints 2 - 3 students as information officers to report directly to the Dean reaction teaching situation. Our school holds faculty leadership, director of the department, teaching management system of attending a lecture with the most direct way to obtain the first hand material for classroom teaching and grasp the teaching dynamic, timely work of teaching problems in process of research and improvement and we have obtained the good effect.

\section{Application of Teaching Quality Guarantee System}

The core of teaching quality assurance system is to improve the quality of teaching and the objective is cultivating high-quality talent. The system should organize each part and respect reasonably, effectively to form an organic system with clear responsibility, standard procedures. Among them, teaching management system is the core, teaching service system is the foundation, teaching evaluation system is fundamental, teaching feedback system is the key and teaching research system is an indispensable booster. They are interdependent to promote each other. Teaching quality guarantee system, once established, can avoid the randomness and blindness in school teaching work to make teaching work step by step on the programmed, standardized track.

Teaching quality guarantee system is a complete system that must be used system analysis methods with integral, comprehensive, structure hierarchy, relativity, dynamic balance, synthesis and analysis of uniformity and other characteristics. Each circulation is associated with the correction of the deviation and new exploration, therefore teaching quality can be continuously improved in the circle.

Human is the main body in the teaching quality guarantee system we must pay full attention to the role of. For example, in the selection of teaching evaluation and supervision personnel, we should teachers with devotion to education, quality consciousness and modern education idea. To fully mobilize the teachers enthusiasm engaged in teaching and research. The majority of teaching management personnel and students also should strengthen the sense of quality to participate in the security system consciously. Only in this way, the teaching quality guarantee system to produce optimal beneficial can be achieved.

\section{References}

[1] The Thought and Methodology for Constructing an Undergraduate Teaching Quality Guarantee System, Teacher Education Research 2007-02.

[2] Improvement of the teaching quality guarantee system at colleges and universities, Journal of Fujian Agriculture and Forestry University 2005-03.

[3] Han Lian, Zhang Bin: The Higher Education Teaching Quality Monitoring System Design , Chinese Higher Education Research 2002-10.

[4] Zhang Yuanzeng: Higher Education Evaluation Method, Fudan University Press.

[5] Gu Mingyuan: Higher Education Evaluation Discussion on Several Problems, Higher Education Development and Evaluation 2006-03. 